\title{
An Investigation On The Liveability Of Urban Settlement. Case Study: Mandy Villa, Segambut, Kuala Lumpur City, Malaysia
}

\author{
Oliver Ling Hoon Leh ${ }^{1, *}$, Muhammad Hanif Abdul Aziz ${ }^{1}$, Marlyana Azyyati Marzukhi ${ }^{1}$ and Abdul Rauf Abdul Rasam ${ }^{1}$ \\ ${ }^{1}$ Environmental \& Social Health Research Group, Faculty of Architecture, Planning \& Surveying, Universiti Teknologi MARA, \\ Selangor, Malaysia.
}

\begin{abstract}
Urban areas are the main centres of growth in every country. However, urban areas face challenges such as environmental destruction, social deprivation, insecurity, health problem, and accessibility issue. These problems affect liveability level of the urban settlements. Liveability is influenced by the aspects of physical environment and social. A study had been carried out in Kuala Lumpur city with the Mandy Villa at Segambut as the study area. The purpose of the study is to investigate the liveability level of the study area and the relationship with the urban planning aspects of physical, and social. A questionnaire survey had been carried out. The respondents with different socio-economic background were mostly felt that the study area was liveable. From the relationship analysis by using correlation tests, the study found that some of the physical planning aspects and most of the social aspects were positively and significantly correlated to the liveability level. With the research findings, town planners, developers and government agencies are able to have a better understanding of the physical and social determinants of liveability. However, more future studies should be carried out for different cities and towns to further improve the understanding on the topic of urban liveability.
\end{abstract}

\section{Introduction}

There is an interest of research for urban planning which focuses on the integrated issue of liveability in relation to development and expansion of cities in developed and growing countries. Liveability study has become an important tool to plan and manage the sustainable and liveable urban settlements. According to a publication [1], built environment interventions designed to reduce non-communicable diseases and health inequity. Besides, the urban planning and design should complement urban planning agendas which focused on creating more liveable, compact, pedestrian-friendly, less automobile-dependent and more socially inclusive cities.

Urban areas are the main centres of economic, social and political growth in every country that have been proved itself as the most attractive places to build wealth, creativity and innovation. However, urban areas face important challenges, including physical and environmental destruction, social deprivation, insecurity, health problem, lack of qualified housing, and traffic congestion. For instance, the low-quality housing does not fulfill the basic needs of the end-user [2]. Besides, housing quality and space determine the success or failure of a community [2].

These urban challenges reduce the quality of life and effect liveability level. Due to the fast paced urban development in Malaysia, it has become a vital issue to explore as to what is happening in the life of people who have settled in the most developed city (Kuala Lumpur).

\section{Literature review}

Liveability is the sum of the factors that add up to a community's quality of life including the built and natural environments, economic prosperity, social stability and equity, educational opportunity, cultural, entertainment and recreation possibilities [3]. Liveability thus touches on sustainability, quality of life, and place design with special attention to people and their location. Place reflects the particular environmental features and socially constructed settings in which people interact with others and with nature [4].

Based on the Connecticut Commission on Women, Children and Seniors [5], the elements of liveability were divided into two categories which are the physical environment and social environment (Figure 1).

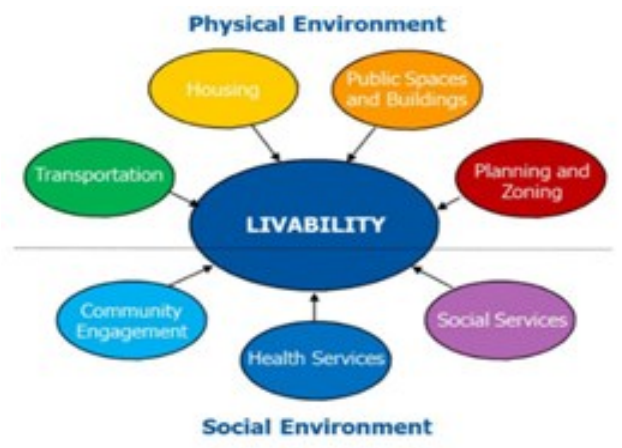

Fig. 1. Relationship of liveability with physical and social environments [5]

\footnotetext{
* Corresponding author: author@e-mail.org
} 
In the categories of physical environment, there is divide into four aspects such as transportation, housing, public space and building and planning and zoning. For the social environment category, there are separated into three aspects which are community engagement, health services and social services.

In the aspect of transportation, it is about creating diverse, accessible and affordable transportation choices that give benefit to everyone. Lowered vehicular congestion and air pollution can be achieved by reduced private vehicle trips and improved connectivity between resident and economic opportunities. It can reduce household transportation cost, freeing up income for other purposes [6]. According to US Government [7] develop safe, reliable, and economical transportation choices will decrease household transportation costs, reduce the dependency on oil, improve air quality, reduce greenhouse gas emissions, and promote public health.

In addition, liveable communities are ones that promote the health and well-being of all residents, including older adults [5]. It is argued that at least half of all health outcomes may be driven by community conditions such as access to quality and affordable housing in walkable neighbourhoods, broad transportation options, and community safety[5].

For Australian cities, the index of liveability was measured based on a survey of Australian city residents which covered 17 attributes that relate to safety, accessibility, affordability, health, diversity of social, cultural and recreational opportunities, congeniality, environmental sustainability and quality of urban design and amenity [8].

Based on this case study by Rama, Yogesh, and Alka Bharat [9], in India, there were eight indicators used in measuring the liveability of a neighbourhood. The eight indicators which were safety, recreation and amenities, community space, infrastructure and public services, housing option, cleanliness and natural environment, good connectivity and lastly distinct characteristic. The selection of indicators was made based on the importance of the indicators in assessing liveability performance based on the local context.

\section{Case study and methods}

This study was focused on the liveability level of urban settlements and the relationship between physical and social aspects of urban planning and liveability. Liveability level was measured based on the perception of residents in the study area (Mandy Villa, Segambut, Kuala Lumpur city). The physical and social aspects were measured based on the satisfaction and comments by residents on the selected aspects (Table 1).
Table 1. Physical and social aspects of liveability used in the study

\begin{tabular}{|c|c|}
\hline Physical aspects & Social aspects \\
\hline $\begin{array}{l}\text { 1. Accessibility to public } \\
\text { transportation facilities. } \\
\text { 2. Safe, reliable \& economic } \\
\text { public transportation. } \\
\text { 3. Quality of car parking } \\
\text { facilities. } \\
\text { 4. Quality of children } \\
\text { playground. } \\
\text { 5. Quality of housing indoor } \\
\text { spaces in the apartment. } \\
\text { 6. Quality of gymnasium } \\
\text { facility in the apartment. } \\
\text { 7. Level of cleanliness. } \\
\text { 8. Level of air quality. } \\
\text { 9. Level of noise. }\end{array}$ & $\begin{array}{l}\text { 1. Safety (and without } \\
\text { harassment). } \\
\text { 2. The sense of } \\
\text { community. } \\
\text { 3. Community } \\
\text { interaction. } \\
\text { 4. Volunteerism. } \\
\text { 5. Happiness. } \\
\text { 6. Healthiness. }\end{array}$ \\
\hline
\end{tabular}

\subsection{Case Study}

Mandy Villa is a medium cost apartment located in the Sentul-Manjalara zone of Kuala Lumpur city. The apartment was built in 2005 with 6.65 acres of size. It comprises four (4) blocks of buildings with 12 stories in height. The total units of residential were 288. Mandy Villa was equipped with outdoor children playground, indoor gymnasium room and car parks. Figure 2 shows the satellite image of the study area.

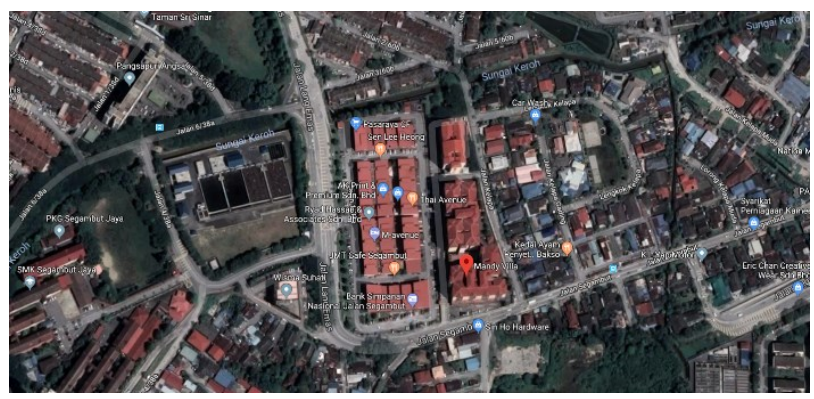

Fig. 2. Satellite image of the study area.

\subsection{Questionnaire Survey}

The liveability level and the satisfaction of residents with the physical and social aspects were identified through a questionnaire survey. A total of 95 respondents were selected from the total apartment units of 288 in the study area by using convenient simple random sampling method. The samples covered both male and female, different ethnic groups, and different age groups. Table 2 shows the background of the respondents. 
Table 2. Background of respondents

\begin{tabular}{|l|r|}
\hline \multicolumn{1}{|c|}{ Variables } & \% \\
\hline Gender & \\
Male & 45.3 \\
Female & 54.7 \\
\hline Ethnicity & \\
Malay & 28.4 \\
Malaysian Chinese & 45.3 \\
Malaysian Indian & 17.9 \\
Others & 8.4 \\
\hline Age & \\
20-29 & 7.4 \\
$30-39$ & 45.2 \\
$40-49$ & 39.0 \\
50 and above & 8.4 \\
\hline Household size & \\
1-2 & 9.5 \\
3-4 & 37.9 \\
5 6 & 48.4 \\
7 or more & 4.2 \\
\hline
\end{tabular}

\subsection{Method of Analysis}

The data were analysed using the Frequency, Crosstabulation, and Correlation tests as provided in the Statistical Package for Social Science (SPSS) software. The purpose of the analysis is to find out the liveability level and the relationship between physical and social aspects of urban planning and liveability level.

\section{Results and discussion}

For the analysis of liveability, the respondents' satisfaction on the physical aspects of the study area was discussed. Then followed by the satisfaction of social aspects. Lastly, the discussion was focused on the overall liveability level of the study area and the relationship with the satisfaction of respondents on the physical and social aspects.

\subsection{Physical aspects of liveability}

For the physical aspects of the study area, most of the respondents were satisfied with the most of the physical elements of the study area, i.e. the parking facilities, playground, apartment indoor space quality, gymnasium facilities, and cleanliness of the study area. However, most of the respondents were dissatisfied with the accessibility to public transportation facilities, quality of the public transportation, air quality and noise levels.

Most of the respondents were dissatisfied with the accessibility to the nearby public transportation facilities i.e. the bus stops and commuter station (Table 3). Furthermore, most of the respondents also not satisfied with the quality (safe, reliable and economic) of public transportation services (Table 3). Based on the comments from respondents, the buses i.e. the Rapid KL buses were always fully occupied by foreign workers. It had made respondents felt uncomfortable in using the bus.
Table 3. Public transportation

\begin{tabular}{|l|c|c|}
\hline \multicolumn{1}{|c|}{ Satisfaction } & $\begin{array}{c}\text { Accessibility to } \\
\text { public transport } \\
\text { facilities (\% of } \\
\text { respondent) }\end{array}$ & $\begin{array}{c}\text { Safe, reliable \& } \\
\text { economic public } \\
\text { transportation (\% } \\
\text { of respondent) }\end{array}$ \\
\hline Very dissatisfied & 0.0 & 0.0 \\
\hline Dissatisfied & $\mathbf{4 6 . 4}$ & $\mathbf{4 8 . 3}$ \\
\hline Neutral & 36.8 & 45.3 \\
\hline Satisfied & 16.8 & 5.3 \\
\hline Very satisfied & 0.0 & 1.1 \\
\hline Total & 100.0 & 100.0 \\
\hline
\end{tabular}

For the aspects of air quality and noise levels at study area, most of the respondents were dissatisfied with the levels (Table 4). The study area (Mandy villa) is surrounded by commercial activities. Besides, there was a sewerage treatment plant located adjacent to the northern part of the study area.

Table 4. Level of air quality and noise

\begin{tabular}{|l|c|c|}
\hline \multicolumn{1}{|c|}{ Satisfaction } & Air quality (\%) & Noise (\%) \\
\hline Very dissatisfied & 6.3 & 6.3 \\
\hline Dissatisfied & $\mathbf{3 5 . 8}$ & $\mathbf{4 0 . 0}$ \\
\hline Neutral & 43.2 & 33.7 \\
\hline Satisfied & 14.7 & 15.8 \\
\hline Very satisfied & 0.0 & 4.2 \\
\hline Total & 100.0 & 100.0 \\
\hline
\end{tabular}

For the facilities in the study area, most of the respondents were satisfied with it. Around $67 \%$ of respondents were satisfied with the parking facilities (Table 5). The parking units were adequate and equipped with sufficient lighting for the convenience and security of the respondents. Besides, almost half of the respondents were satisfied with the children playground provided in the study area (Table 5). Besides the playground, most of the respondents also satisfied with another type of recreational/exercise facility i.e. the gymnasium facilities in the study area (Table 6). As refer to the Table 7 , most of the respondents were moderately satisfied with the housing indoor space quality and level of cleanliness of the study area.

Table 5. Quality of car parks and children playground

\begin{tabular}{|l|c|c|}
\hline \multicolumn{1}{|c|}{ Satisfaction } & $\begin{array}{c}\text { Car parking } \\
\text { facilities (\%) }\end{array}$ & $\begin{array}{c}\text { Children } \\
\text { playground (\%) }\end{array}$ \\
\hline Very dissatisfied & 0.0 & 0.0 \\
\hline Dissatisfied & 0.0 & 0.0 \\
\hline Neutral & 8.4 & 45.2 \\
\hline Satisfied & $\mathbf{6 7 . 4}$ & $\mathbf{4 9 . 5}$ \\
\hline Very satisfied & 24.2 & 5.3 \\
\hline Total & 100.0 & 100.0 \\
\hline
\end{tabular}


Table 6. Quality of gymnasium facility in the apartment

\begin{tabular}{|l|c|}
\hline \multicolumn{1}{|c|}{ Satisfaction } & \% \\
\hline Very dissatisfied & 0.0 \\
\hline Dissatisfied & 0.0 \\
\hline Neutral & 34.7 \\
\hline Satisfied & $\mathbf{5 8 . 9}$ \\
\hline Very satisfied & 6.4 \\
\hline Total & 100.0 \\
\hline
\end{tabular}

Table 7. Quality of housing indoor spaces and cleanliness in the apartment

\begin{tabular}{|l|c|c|}
\hline \multicolumn{1}{|c|}{ Satisfaction } & $\begin{array}{c}\text { Housing indoor } \\
\text { spaces } \mathbf{( \% )}\end{array}$ & Cleanliness (\%) \\
\hline Very dissatisfied & 0.0 & 0.0 \\
\hline Dissatisfied & 24.2 & 0.0 \\
\hline Neutral & 23.2 & 54.7 \\
\hline Satisfied & $\mathbf{3 7 . 9}$ & $\mathbf{4 1 . 1}$ \\
\hline Very satisfied & 14.7 & 4.2 \\
\hline Total & 100.0 & 100.0 \\
\hline
\end{tabular}

\subsection{Social aspect of liveability}

Among the six aspects of social, there were three of it can be considered as not satisfied by most of the respondents, which were the sense of community, community interaction, and volunteerism (Table 8 and Table 9). It showed that the level of social cohesion was low in the study area, as measured by the three aspects. There were almost $80 \%$ of respondents not satisfied with the level of volunteerism in the study area (Table 8). Most of the people in the study area (an urban setting) were less willing to volunteer themselves for the society. Mostly, urban dwellers were more concern about their own business as compared to the common goods. Add, most of the respondents (44\%) also felt dissatisfaction on the level of community interaction in the study area (Table 8). There were only 19\% of respondents satisfied with the community interaction. As a result, most of the respondents $(40 \%)$ felt dissatisfaction with the sense of community in the study area (Table 9). It means, there was a low level of feeling that respondents have of belonging or they were part of the community.

Table 8. Volunteerism and Community interaction

\begin{tabular}{|l|c|c|}
\hline \multicolumn{1}{|c|}{ Satisfaction } & Volunteerism (\%) & $\begin{array}{c}\text { Community } \\
\text { interaction (\%) }\end{array}$ \\
\hline Very dissatisfied & 0.0 & 0.0 \\
\hline Dissatisfied & $\mathbf{7 7 . 9}$ & $\mathbf{4 4 . 3}$ \\
\hline Neutral & 18.9 & 36.8 \\
\hline Satisfied & 3.2 & 18.9 \\
\hline Very satisfied & 0.0 & 0.0 \\
\hline Total & 100.0 & 100.0 \\
\hline
\end{tabular}

Table 9. Sense of community and Safety (without harassment)

\begin{tabular}{|l|c|c|}
\hline \multicolumn{1}{|c|}{ Satisfaction } & $\begin{array}{c}\text { Sense of } \\
\text { community (\%) }\end{array}$ & $\begin{array}{c}\text { Safety \& without } \\
\text { harassment (\%) }\end{array}$ \\
\hline Very dissatisfied & 0.0 & 0.0 \\
\hline Dissatisfied & $\mathbf{4 0 . 0}$ & 29.5 \\
\hline Neutral & 33.7 & $\mathbf{4 5 . 2}$ \\
\hline Satisfied & 24.2 & 20.0 \\
\hline Very satisfied & 2.1 & 5.3 \\
\hline Total & 100.0 & 100.0 \\
\hline
\end{tabular}

Table 10. Happiness and Healthiness

\begin{tabular}{|l|c|c|}
\hline \multicolumn{1}{|c|}{ Satisfaction } & Happiness (\%) & Healthiness (\%) \\
\hline Very dissatisfied & 0.0 & 0.0 \\
\hline Dissatisfied & 2.1 & 1.1 \\
\hline Neutral & 54.7 & 10.5 \\
\hline Satisfied & $\mathbf{4 1 . 1}$ & $\mathbf{6 6 . 3}$ \\
\hline Very satisfied & 2.1 & 22.1 \\
\hline Total & 100.0 & 100.0 \\
\hline
\end{tabular}

However, most of the respondents (around half) felt neutral on the satisfaction of the safety level in the study area (Table 9). There were only around $30 \%$ of the respondents felt a dissatisfaction with the safety level. Besides, there were around $25 \%$ of the respondents felt either satisfied or very satisfied with the safety of the study area. Most of the respondents (around 55\%) were felt neutral on the aspect of happiness, and around $43 \%$ felt either satisfied or very satisfied with the level of happiness (Table 10). It showed that even the cohesion level is not satisfied by respondents, most of the respondents still felt happy when they were staying in the study area. For the aspect of healthiness, there was only $1 \%$ of respondents felt dissatisfied with the study area. At the same time, there were $66 \%$ felt satisfaction on the healthiness (Table 10). It means, most of them felt that they were healthy.

\subsection{Liveability level and the correlation analysis}

Most of the respondents $(47 \%)$ were feeling that the study area was either liveable or very liveable. However, there were also $19 \%$ felt that it was unliveable (Table 11). By looking on the results of correlation analysis among physical and social aspects, and liveability level, it was found that four physical aspects and five social aspects were significantly correlated to the liveable level based on the perception of respondents (Table 12 and Table 13). All the significantly correlated aspects were positively correlated to the liveable level (refer to the $r$ value in Table 12 and Table 13). It showed that when the satisfaction of the social and physical aspects in Table 12 and Table 13 increased, the liveability level also increased. 
Table 11. Overall liveability level

\begin{tabular}{|l|c|}
\hline \multicolumn{1}{|c|}{ Satisfaction } & \% of respondent \\
\hline Very unliveable & 0.0 \\
\hline Unliveable & 19.0 \\
\hline Neutral & 33.7 \\
\hline Liveable & $\mathbf{4 3 . 1}$ \\
\hline Very liveable & 4.2 \\
\hline Total & 100.0 \\
\hline
\end{tabular}

Table 12. Correlation between liveability and physical aspects

\begin{tabular}{|l|c|c|c|}
\hline \multicolumn{1}{|c|}{ Physical aspects } & \multicolumn{1}{c|}{$\boldsymbol{r}$} & \multicolumn{1}{c|}{$\boldsymbol{p}$} & \multicolumn{1}{c|}{$\begin{array}{c}\text { Sig. } \\
\text { Level }\end{array}$} \\
\hline $\begin{array}{l}\text { Access to public } \\
\text { transport }\end{array}$ & 0.347 & 0.001 & 0.01 \\
\hline $\begin{array}{l}\text { Public transportation } \\
\text { system }\end{array}$ & 0.399 & 0.000 & 0.01 \\
\hline Cleanliness & 0.328 & 0.001 & 0.01 \\
\hline Air quality & 0.246 & 0.016 & 0.05 \\
\hline
\end{tabular}

Note: $r=$ coefficient; $p=$ significant value; Sig. $=$ significant

Other physical aspects were not significant even at 0.05 level

By comparing the social aspects with the physical aspects, it was found that more social aspects were significantly correlated to liveability. Five out of the six social aspects were significantly correlated to liveability. However, there were only four out of the nine physical aspects were significantly correlated to liveability. Besides, it can be noticed that correlation coefficient $(r)$ values of the social aspects were generally larger than physical aspects. Table 12 showed that the correlation coefficient $(r)$ values of the physical aspects were ranging from 0.246 to 0.347 only. However, the correlation coefficient $(r)$ values of social aspects were ranging from 0.236 to 0.708 (Table 13).

Table 13. Correlation between liveability and social aspects

\begin{tabular}{|l|r|r|r|}
\hline \multicolumn{1}{|c|}{ Physical aspects } & \multicolumn{1}{c|}{$\boldsymbol{r}$} & \multicolumn{1}{c|}{$\boldsymbol{p}$} & \multicolumn{1}{c|}{$\begin{array}{c}\text { Sig. } \\
\text { Level }\end{array}$} \\
\hline Volunteerism & 0.708 & 0.000 & 0.01 \\
\hline Safety & 0.527 & 0.000 & 0.01 \\
\hline $\begin{array}{l}\text { Community } \\
\text { interaction }\end{array}$ & 0.519 & 0.000 & 0.01 \\
\hline Sense of community & 0.436 & 0.000 & 0.01 \\
\hline Happiness & 0.236 & 0.021 & 0.05 \\
\hline
\end{tabular}

Note: $r=$ coefficient; $p=$ significant value; Sig. $=$ significant

The aspect of healthiness was not significant even at 0.05 level

\section{Conclusion}

The study area, Mandy Villa which is located in the Kuala Lumpur city was liveable based on the perception of the majority of respondents. There were four physical aspects and five social aspects of planning significantly and positively correlated to the liveability level. The relationship between social aspects and liveability was stronger as compared to the relationship between physical aspects and liveability. It showed that social aspects of planning were stronger and significantly related to the liveability level among respondents in the study area as compared to the physical aspects. Thus, any effort to increase the liveability level as referring to the case study should focus on all the significantly correlated aspects, especially the aspects of volunteerism, safety, community interaction, sense of community, and accessibility.

The authors would like to thank Universiti Teknologi MARA (UiTM) for the support and partly funding the study and publication through the REI research grant (600-RMI/DANA $5 / 3 /$ REI (8/2015)). The authors are also thankful to all the departments, organisations, and individual who had contributed to this study.

\section{References}

1. B. Giles-Corti, H. Badland, G. Turrell, J.N. Rachele, L. Gunn, P. Hooper, Understanding causal relationship between the built and social environment, health and associated behaviours and risk factors. Be Active, Canberra, ACT (2014)

2. A.H. Chohan, A. I. Che-Ani, B.K. Shar, J. Awad, A. Jawaid, N. Mohd Tawil. A model of housing quality determinants (HQD) for affordable housing. Journal of Construction in Developing Countries, 20(1), 117-136 (2015)

3. Partners for Livable Communities. What is livability? Available http://livable.org/aboutus/what-is-livability, Washington, DC, (2018)

4. N.D. Perkins, Livability, Regional Equity, and Capability: Closing in on Sustainable Land Use. University of Baltimore Law Review, 37(2), 157202 (2008)

5. Connecticut Commission on Women, Children and Seniors. Livable communities. Hartford, Connecticut, US, (2017)

6. J.C. Bridger and A.E. Luloff. Building the Sustainable Community: Is Social Capital the Answer? Sociological Inquiry, 71(4), 458-472 (2001)

7. US Government. Advancing Livability Principle: Federal Investment Reform Lessons from the Chicagoland Experience. Recommendation Report. Center for Neigbourhood Technology, Chicago Metropolitan Agency of Planning, Metropolitan Planning Council, \& Regional Transportation Authority, (2009)

8. Department of Infrastructure \& Transport, State of Australian Cities 2011. Canberra ACT, Australia. (2011)

9. Rama Umesh Pandey, Yogesh Kumar Garg and Alka Bharat. Quantitative Approach for Understanding Perspectives on Livability in Indian Context, International Journal on Emerging Technologies, 5(1), 1-7 (2014) 